\title{
Mapping of potentially hazardous elements in the Cambrian- Vendian aquifer system, northern Estonia
}

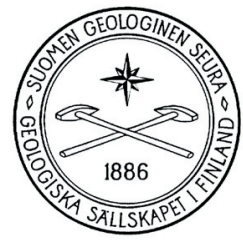

\author{
EnN Karro* and Andres Marandi \\ Institute of Geology, University of Tartu, Vanemuise 46, 51014 Tartu, Estonia
}

\begin{abstract}
Communities and towns in northern Estonia rely upon either surface waters or groundwater from Cambrian-Vendian aquifer system with limited fresh water resources. The composition of groundwater is controlled, among other factors, by the lithologic composition of water-bearing rocks and sediments. The peculiarities of the rock matrix may locally restrict the use of groundwater as a source of water supply. The distribution of fluorine, barium and arsenic has been studied in northern Estonian water supply wells. The results of the hydrogeochemical mapping enable to delimit the barium anomaly in the Cambrian-Vendian aquifer system. Vertical distribution of studied compounds and hydraulic connection between water-bearing Vendian sediments with underlying crystalline basement refers the weathered basement rocks as the plausible source of barium and fluorine in groundwater. The elevated concentrations of barium and fluorine detected in groundwater from North Estonian wells may become a source of growing concern in Estonia. The results of hydrochemical research should be transformed to instructions how to avoid or eliminate the quality problems in the risk areas.
\end{abstract}

Key words: groundwater, aquifers, fluorine, barium, arsenic, bedrock, Cambrian, Vendian, Estonia

\section{Introduction}

First regional study of micro compounds in the Cambrian-Vendian aquifer system in Estonia was performed in 1994, but did not include barium (Savitskaja \& Viigand, 1994). According to later findings (Otsa \& Tamm, 1997; Tamm, 1998), barium concentration exceeded the limit value of the previous Estonian drinking water standard $0.7 \mathrm{mg} / \mathrm{l}$ (Joogivesi, 1995) in several locations, with maximum concentrations $(9 \mathrm{mg} / \mathrm{l})$ found in the water supply of Kohtla-Järve town.

New drinking water standard (Joogivee, 2001), which is compatible with the Drinking Water Directive of European Union (98/ 83/EEC) does not limit barium concentration. However, it cannot be supposed that the EU standard does not consider barium being toxic. The Environmental Protection Agency of the

* Corresponding author

e-mail: ekarro@ut.ee
United States (US EPA) has set the maximum concentration limit (MCL) for barium in the drinking water at $2.0 \mathrm{mg} / \mathrm{l}$. World Health Organisation has published a guideline value 0.7 $\mathrm{mg} / \mathrm{l}$ for barium (WHO, 1996). According to EPA, if people are exposed to barium at levels above the MCL for relatively short periods of time, gastrointestinal disturbances and muscular weakness may result. A lifetime exposure at levels above MCL may lead to high blood pressure diseases. If barium levels were found to be consistently above the MCL, the water suppliers had to use water treatment methods for barium removal (EPA, 1995).

Fluorine is an important microelement, needed by man and higher animals as a constituent of teeth and bones. Unlike most of the other essential elements, a large portion of fluorine is ingested from drinking water. Health problems arising from excess fluoride intake (dental fluorosis) have been recorded in Estonia (Saava, 


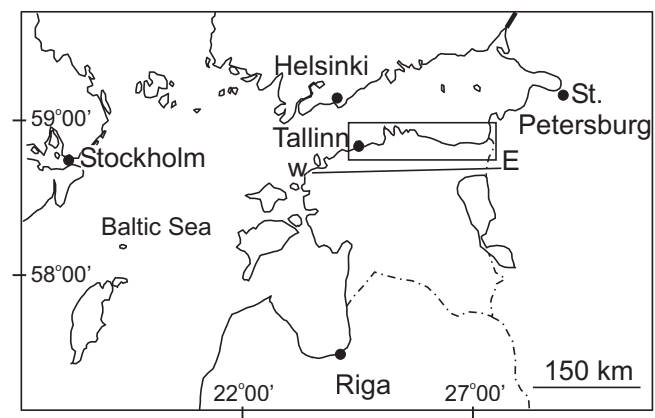

Fig. I. Location of the study area and the line of hydrogeological cross-section (W-E)

1998; Russak et al., 2002). On the other hand, in most of the North-Estonian wells F- concentrations in drinking water are below the limit value (Savitskaja \& Viigand, 1994). However, the occurrence and hydrochemistry of fluorine and arsenic in the Cambrian-Vendian aquifer system is incompletely studied so far, and needs more detail approach in terms of sampling density as well as hydrogeochemical interpretations.

The aim of this study is to map the areal distribution of $\mathrm{Ba}^{2+}$, As and $\mathrm{F}^{-}$, and find the geological sources for the probable anomalies of these compounds in the Cambrian-Vendian aquifer system in northern Estonia. The results of the current study contribute to the understanding of the reasons of natural groundwater contamination and help to work out the strategies for water supply.

\section{General geological and hydrogeo- logical setting}

Estonia, covering $45000 \mathrm{~km}^{2}$ of land area, is situated in the northwestern part of the EastEuropean Platform. Structurally, its sedimentary beds, lying on the southern slope of the Fennoscandian Shield, are declined southwards at about 3-4 metres per kilometre. Crystalline Palaeoproterozoic basement is overlain by Neoproterozoic (Vendian) and Palaeozioc (Cambrian, Ordovician, Silurian and Devonian) sedimentary rocks covered by Quaternary deposits.
In study area (Fig. 1), the Vendian, Cambrian and Ordovician rocks are the only sedimentary rocks covering the crystalline basement which lies approximately in the depth of 150 m (Fig. 2). The crystalline basement consisting mostly of gneisses and biotite gneisses (Koistinen et al., 1996) is in its upper 10-150 m thick portion fractured and weathered. Weathering profiles are composed predominantly of kaolinite, illite, chlorite and montmorillonite, depending on original bedrock composition and intensity of weathering.

Weathered basement rocks are overlaid by water-bearing Vendian and Cambrian silt- and sandstones, which form the Cambrian-Vendian aquifer system. In eastern part of Estonia Vendian sedimentary rocks are divided by clay layer of Kotlin Formation $\left(\mathrm{V}_{2} \mathrm{kt}\right.$ ) into the Voronka $\left(\mathrm{V}_{2} \mathrm{vr}\right)$ and $\mathrm{Gdov}\left(\mathrm{V}_{2} \mathrm{gd}\right)$ aquifers (Fig. 2). The upper, the Voronka aquifer, consists of quartzose sand- and siltstones having hydraulic conductivity of 0.6 to $12.5 \mathrm{~m} / \mathrm{d}$ and transmissivity of $100-150 \mathrm{~m}^{2} / \mathrm{d}$. The lower, the Gdov aquifer, is formed of mixed-grained sand- and siltstones, the conductivity of which varies $0.5-9.2 \mathrm{~m} / \mathrm{d}$ while the transmissivity is about $300 \mathrm{~m}^{2} / \mathrm{d}$ (Perens \& Vallner, 1997).

The Cambrian-Vendian aquifer system is covered by clays of Lower Cambrian Lontova Formation, which form laterally continuous Lontova aquitard. This aquitard has a strong isolation capacity, as its transversal conductivity is predominantly $10^{-7}-10^{-5} \mathrm{~m} / \mathrm{d}$ (Perens \& Vallner, 1997). Lontova clays have the thickness of 60-90 $\mathrm{m}$ in northeastern Estonia (Fig. 2). Westwards from Tallinn the Lontova Formation is gradually replaced by interbedding clay and sandstone deposits of the Voosi Formation, which attain a thickness of $90 \mathrm{~m}$ in southwestern Estonia. On the western Estonian islands, the Vendian deposits have also been pinched out and the water-bearing terrigenous rocks consist only of Cambrian sand- and siltstones with interlayers of clay.

The Cambrian-Vendian aquifer system is distributed throughout Estonia, except the LoknoMõniste uplift area in southern Estonia. Water- 


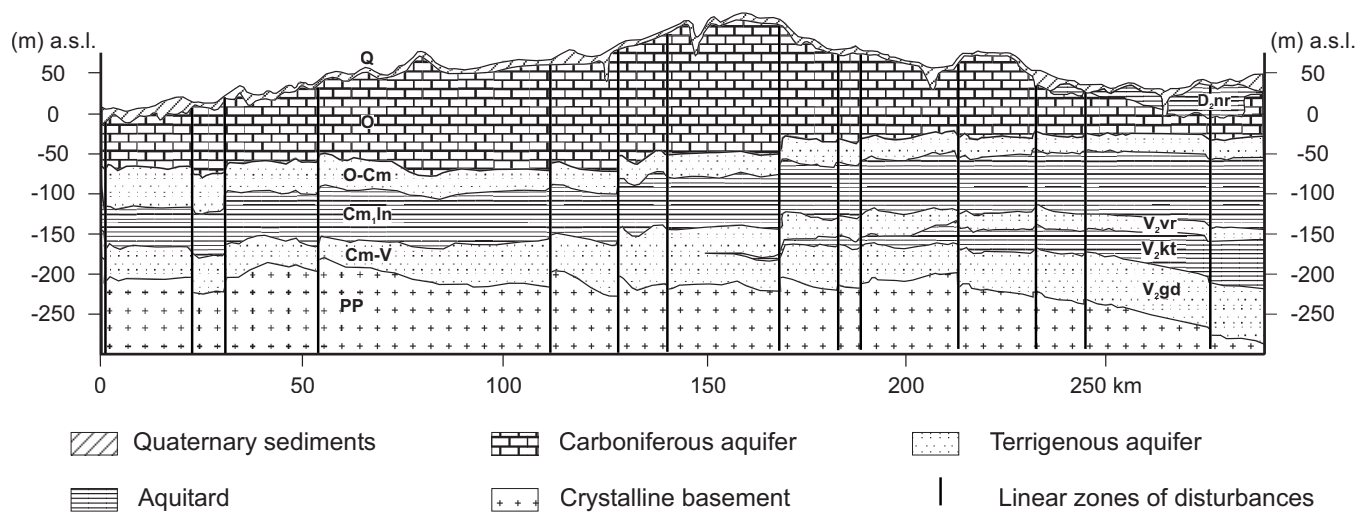

Fig. 2. Hydrogeological cross-section of North-Estonia. Q: Quaternary sediments, $D_{2} n r$ : Narva aquitard, O: Ordovician aquifer system, O-Cm: Ordovician-Cambrian aquifer system, $\mathrm{Cm}$ In: Lontova aquitard, Cm-V: Cambrian-Vendian aquifer system, $\mathrm{V}_{2} \mathrm{vr}$ : Voronka aquifer, $\mathrm{V}_{2} \mathrm{kt}$ : Kotlin aquitard, $\mathrm{V}_{2} \mathrm{gd}$ : Gdov aquifer, PP: Paleoproterozoic crystalline basement. Line of section shown in Fig. I.

bearing Cambrian and Vendian sedimentary rocks as well as clays of the Lontova Formation pinch out in the bottom of Finnish Gulf, about $20 \mathrm{~km}$ northward from the coastline.

Intensive erosional processes in pre-Quaternary, inter-, late- and postglacial times have formed erosional valleys, cutting through the Lontova aquitard (Tavast, 1997). These ancient buried valleys are filled with Quaternary sediments, mostly by till, but also the marine, glaciofluvial and glaciolacustrine sediments are presented. The valleys have north-west to south-east direction, thus being approximately perpendicular to the North-Estonian coastline. In places, where groundwater is intensively abstracted, valleys provide the Cambrian-Vendian aquifer system with fresh meteoric water.

The variations in the groundwater salinity and the associations of chemical compounds dominating in water can be followed both in vertical and horizontal direction. Fresh groundwaters of $\mathrm{Na}-\mathrm{Ca}-\mathrm{HCO}_{3}-\mathrm{Cl}$ and $\mathrm{Ca}-\mathrm{Na}-\mathrm{Cl}-$ $\mathrm{HCO}_{3}$ type with total dissolved solids (TDS) value, mainly below $1.0 \mathrm{~g} / \mathrm{l}(0.4-1.1 \mathrm{~g} / \mathrm{l})$, are characteristic in northern Estonia (Savitskaja \& Viigand, 1994; Perens et al., 2001; Marandi et al., 2002). In Central- and South-Estonia, as well as in the Gdov aquifer in northeastern Estonia, the TDS content rises up to 2-22 g/l and the $\mathrm{Na}-\mathrm{Cl}, \mathrm{Na}-\mathrm{Ca}-\mathrm{Cl}$ and $\mathrm{Ca}-\mathrm{Na}-\mathrm{Cl}$ type groundwaters dominate (Karise, 1997; Mokrik, 1997; Perens et al., 2001).

The Cambrian-Vendian aquifer system is used for the water supply in northern Estonia only, because in the southern part of country the water-bearing layers are too deep and the salinity of water is high. In northern Estonia however, the supply is very significant, amounting to $10-$ $13 \%$ of the Estonian groundwater consumption. In Ida-Virumaa and Harjumaa counties the share of Cambrian-Vendian groundwater consumption is about $75 \%$ and in Lääne-Virumaa almost 50 \% (Savitskaja, 1999). The saline groundwater resources in South-Estonia can be used as mineral water (Karise, 1997).

\section{Materials and methods}

During 2001 and 2002, 47 groundwater samples were collected from North Estonia. The sampling points were selected according to the following criteria: 1) assurance of a good areal representation and 2) sampling of both Gdov and Voronka aquifers at every sampling point, if possible. All sampled wells are water supply wells and under operation at the moment. Groundwater samples were taken after the field parameters (redox potential, $\mathrm{pH}$, electrical conductivity and temperature) were stabilised in the pumped-out water. 
In 2001, two laboratories of the Estonian Environmental Research Centre (Tallinn and Jōhvi), that are accredited by the Estonian Standard Board (Reg. no L008 and L081, respectively) were used and the concentrations of $\mathrm{Cl}^{-}, \mathrm{SO}_{4}^{2-}, \mathrm{HCO}_{3}^{-}, \mathrm{Ca}^{2+}, \mathrm{Mg}^{2+}, \mathrm{K}^{+}, \mathrm{Na}^{+}, \mathrm{Fe}, \mathrm{F}^{-}$, As, $\mathrm{Ba}^{2+}$ were determined. The quantification limit for sulphate is $1 \mathrm{mg} / \mathrm{l}$ in Tallinn and $2 \mathrm{mg} /$ $\mathrm{l}$ in the Jôhvi laboratory.

In 2002, water samples were analysed in the Tartu Environmental Research laboratory (Reg. no $\mathrm{L} 100)$ where $\mathrm{Cl}^{-}, \mathrm{SO}_{4}{ }^{2-}, \mathrm{HCO}_{3}^{-}, \mathrm{Ca}^{2+}, \mathrm{Mg}^{2+}$, $\mathrm{K}^{+}, \mathrm{Na}^{+}, \mathrm{Fe}$ and $\mathrm{Ba}^{2+}$ were determined. The quantification limit for sulphate is $0,2 \mathrm{mg} / \mathrm{l}$ in Tartu laboratory.

For data processing, interpretation and hydrogeochemical assessment of the results, MapInfo Professional 6.0 and AquaChem 3.7 were used.

\section{Results and discussion}

Groundwater abstracted from studied wells is directly distributed between consumers without any purification. As an exception, the mixing of groundwater originated from the Cambrian-Vendian and Quaternary aquifer systems, respectively, is used to lower the TDS content in Kohtla-Järve. Thus, it is supposed that the groundwater chemistry is in accordance with the limit values set by drinking water standard (Joogivee, 2001). Results of the groundwater analyses performed within current study are presented in Table 1. Generally, the groundwater has a good quality. The problems are associated with elevated $\mathrm{Fe}$ contents, reaching up to 6-7 $\mathrm{mg} / \mathrm{l}$ and exceeding the limit value set by standard 30-35 times. The quality of groundwater does not always fulfil the requirements in case of $\mathrm{Cl}^{-}$and $\mathrm{Na}^{+}$(Table 1).

The chemical type of Cambrian-Vendian groundwater varies from $\mathrm{Ca}-\mathrm{HCO}_{3}$ to $\mathrm{Na}$ $\mathrm{Cl}$, being mostly $\mathrm{Na}-\mathrm{Ca}-\mathrm{Cl}-\mathrm{HCO}_{3}$ (Fig. 3). Ca$\mathrm{HCO}_{3}$ type of water is characteristic for the areas around the ancient buried valleys, where water exchange between fresh groundwater from overlying aquifers and the Cambrian-Vendian aqui-

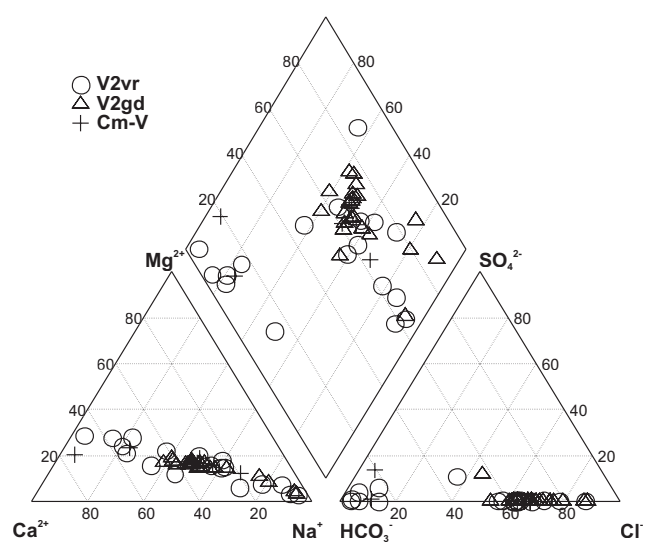

Fig. 3. Piper plot showing the composition of groundwater in the study area. $\mathrm{V}_{2}$ vr:Voronka aquifer, $\mathrm{V}_{2}$ gd: Gdov aquifer, Cm-V: Cambrian-Vendian aquifer system.

fer system occurs. The TDS content of groundwater range from 120 to $1531 \mathrm{mg} / \mathrm{l}$ in study area (Table 1), whereas the lower values are usually connected with $\mathrm{Ca}-\mathrm{HCO}_{3}$ type mixed and freshened water. The increase in TDS content in the lower (Gdov) aquifer can be followed in the eastern part of study area, where the Cambrian-Vendian aquifer system is divided by the Kotlin aquitard into two aquifers (Fig. 2). The content of major ionic species $\left(\mathrm{Ca}^{2+}, \mathrm{Na}^{+}, \mathrm{Mg}^{2+}\right.$, $\mathrm{HCO}_{3}^{-}, \mathrm{Cl}^{-}$) in groundwater is variable, except of $\mathrm{SO}_{4}^{2-}$ which is very low (Table 1 ). The highest sulphate concentrations are usually detected in wells locating close to buried valleys, where dilution of groundwater has contributed the development of oxidising environment.

\section{I. Fluorides}

Fluorides have been in the focus of public and scientific interest because of their important physiological role in the human health. Their beneficial effect in decreasing the incidence of dental caries is well known as well as their toxicity, when occurring in abundance in drinking water, causing diseases such as dental and skeletal fluorosis (Lahermo et al., 1991; Yong \& Hua, 1991; Grimaldo et al., 1995; Apambire et al., 1997; Yang et al., 2000). 
Table I. Hydrochemical properties of groundwater in Cambrian-Vendian aquifer system compared to the limit values set by standard. Concentrations in $\mathrm{mg} / \mathrm{l} . \mathrm{V}_{2}$ vr: Voronka aquifer, $\mathrm{V}_{2}$ gd: Gdov aquifer, $\mathrm{Cm}-\mathrm{V}$ : Cambrian-Vendian aquifer system.

\begin{tabular}{|c|c|c|c|c|c|c|c|c|c|c|c|c|c|c|c|}
\hline Site & Aquifer & Year & $\mathrm{pH}$ & TDS & $\mathrm{Ca}^{2+}$ & $\mathrm{Mg}^{2+}$ & $\mathrm{Na}^{+}$ & $\mathrm{K}^{+}$ & $\mathrm{Cl}^{-}$ & $\mathrm{HCO}_{3}^{-}$ & $\mathrm{SO}_{4}^{2-}$ & $\mathrm{Fe}$ & $\mathrm{Ba}^{2+}$ & As & $\mathrm{F}^{-}$ \\
\hline 1 & $\mathrm{~V}_{2} \mathrm{gd}$ & 2001 & 8.3 & 224 & 30.0 & 8.5 & 34.0 & 7.0 & 62.0 & 103.7 & 22.0 & 0.56 & 0.20 & $<0.001$ & 0.78 \\
\hline 2 & $\mathrm{~V}_{2} \mathrm{vr}$ & 2001 & 8.3 & 304 & 26.0 & 8.5 & 26.5 & 6.0 & 46.0 & 115.9 & 19.0 & 0.59 & 0.12 & $<0.001$ & 0.85 \\
\hline 3 & $\mathrm{~V}_{2} \mathrm{gd}$ & 2001 & 7.9 & 865 & 84.0 & 22.0 & 97.5 & 8.0 & 304.0 & 176.9 & $<1$ & 1.30 & 0.35 & 0.002 & 0.45 \\
\hline 4 & $\mathrm{~V}_{2} \mathrm{vr}$ & 2001 & 7.8 & 1450 & 188.0 & 36.0 & 150.0 & 8.5 & 615.0 & 152.5 & $<1$ & 7.50 & 0.51 & 0.003 & 0.40 \\
\hline 5 & $\mathrm{~V}_{2} \mathrm{gd}$ & 2001 & 7.7 & 936 & 116.0 & 27.0 & 115.0 & 9.0 & 184.0 & 183.0 & $<1$ & 1.90 & 0.43 & $<0.001$ & 0.36 \\
\hline 6 & $\mathrm{~V}_{2} \mathrm{vr}$ & 2002 & 8.2 & 610 & 77.8 & 13.1 & 93.0 & 7.7 & 220.0 & 220.0 & $<0.2$ & 0.55 & 0.88 & & \\
\hline 7 & $\mathrm{Cm}-\mathrm{V}$ & 2002 & 7.9 & 200 & 36.1 & 9.5 & 18.0 & 5.5 & 13.0 & 190.0 & 1.9 & 0.31 & 0.14 & & \\
\hline 8 & $\mathrm{~V}_{2} \mathrm{vr}$ & 2002 & 8.2 & 120 & 21.3 & 4.9 & 10.0 & 3.4 & 7.2 & 99.0 & 5.6 & 0.13 & 0.08 & & \\
\hline 9 & $\mathrm{Cm}-\mathrm{V}$ & 2002 & 7.3 & 200 & 48.5 & 8.0 & 3.8 & 1.9 & 6.6 & 160.0 & 21.0 & 3.70 & 0.08 & & \\
\hline 10 & $\mathrm{Cm}-\mathrm{V}$ & 2002 & 7.9 & 450 & 43.7 & 14.8 & 97.0 & 7.9 & 190.0 & 170.0 & $<0.2$ & 1.10 & 0.99 & & \\
\hline 11 & $\mathrm{~V}_{2} \mathrm{vr}$ & 2002 & 7.8 & 190 & 40.9 & 11.9 & 12.0 & 6.5 & 4.7 & 220.0 & 0.3 & 0.63 & 0.25 & & \\
\hline 12 & $\mathrm{~V}_{2} \mathrm{vr}$ & 2002 & 7.9 & 170 & 38.5 & 12.9 & 19.0 & 7.4 & 9.1 & 230.0 & $<0.2$ & 0.66 & 0.21 & & \\
\hline \multirow[t]{2}{*}{13} & $V_{2} g d$ & 2001 & 7.7 & 1020 & 88.0 & 24.0 & 128.0 & 10.0 & 345.0 & 201.3 & $<1$ & 6.70 & 2.41 & 0.001 & 0.91 \\
\hline & & 2002 & 7.7 & 630 & 97.8 & 23.1 & 120.0 & 9.9 & 330.0 & 180.0 & $<0.2$ & 0.70 & 2.60 & & \\
\hline 14 & $\mathrm{~V}_{2} \mathrm{vr}$ & 2001 & 7.7 & 396 & 34.0 & 16.0 & 98.0 & 8.5 & 150.0 & 201.3 & $<1$ & 0.35 & 0.77 & $<0.001$ & 0.52 \\
\hline 15 & $\mathrm{Cm}-\mathrm{V}$ & 2002 & 7.8 & 500 & 60.6 & 18.7 & 100.0 & 8.6 & 220.0 & 180.0 & 0.5 & 0.46 & 1.50 & & \\
\hline 16 & $V_{2} \mathrm{gd}$ & 2002 & 7.9 & 380 & 41.3 & 12.4 & 92.0 & 7.9 & 140.0 & 210.0 & $<0.2$ & 0.89 & 0.82 & & \\
\hline 17 & $\mathrm{Cm}-\mathrm{V}$ & 2002 & 7.8 & 530 & 56.5 & 17.7 & 100.0 & 7.9 & 220.0 & 180.0 & $<0.2$ & 0.30 & 0.79 & & \\
\hline 18 & $\mathrm{~V}_{2} \mathrm{vr}$ & 2002 & 8.0 & 330 & 35.7 & 14.1 & 66.0 & 8.0 & 29.0 & 320.0 & $<0.2$ & 0.55 & 2.10 & & \\
\hline \multirow[t]{2}{*}{19} & $V_{2} \mathrm{gd}$ & 2001 & 7.8 & 936 & 87.0 & 26.0 & 140 & 8.0 & 323.0 & 9 & $<1$ & 2.00 & 5.41 & 0.003 & 0.96 \\
\hline & & 2002 & 7.8 & 810 & 87.0 & 25.5 & 140.0 & 10.0 & 320.0 & 240.0 & $<0.2$ & 1.50 & 4.70 & & \\
\hline \multirow[t]{2}{*}{20} & $V_{2} g d$ & 2001 & 8.3 & 866 & 80.0 & 26.0 & 130.0 & 8.0 & 323.0 & 262.4 & $<1$ & 3.30 & 6.08 & 0.003 & 1.00 \\
\hline & & 2002 & 7.6 & 930 & 89.0 & 26.2 & 150.0 & 10.0 & 350.0 & 230.0 & 0.3 & 3.00 & 5.30 & & \\
\hline 21 & $\mathrm{~V}_{2} \mathrm{gd}$ & 2002 & 7.7 & 780 & 93.0 & 26.0 & 140.0 & 10.0 & 330.0 & 230.0 & 0.5 & 3.80 & 4.60 & & \\
\hline 22 & $\mathrm{~V}_{2} \mathrm{vr}$ & 2002 & 7.5 & 260 & 63.8 & 16.5 & 48 & 4.1 & 6.0 & 290.0 & 2.6 & 3.10 & 0.46 & & \\
\hline 23 & $\mathrm{~V}_{2} \mathrm{vr}$ & 2002 & 7.7 & 330 & 65.0 & 17.0 & 27.0 & 8.5 & 10.0 & 340.0 & 12.0 & 0.69 & 2.30 & & \\
\hline 24 & $V_{2} \mathrm{gd}$ & 2002 & 7.8 & 660 & 75.4 & 20.9 & 120.0 & 9.2 & 250.0 & 240.0 & $<0.2$ & 1.30 & 5.90 & & \\
\hline 25 & $\mathrm{Cm}-\mathrm{V}$ & 2001 & 7.8 & 658 & 61.1 & 23.0 & 115.0 & 8.5 & 220.0 & 242.8 & 2.0 & 1.10 & 3.77 & 0.001 & 1.07 \\
\hline 26 & $V_{2} g d$ & 2001 & 8.0 & 643 & 62.1 & 20.3 & 115.0 & 8.0 & 235.0 & 247.7 & 2.0 & 0.89 & 3.97 & 0.001 & 1.14 \\
\hline 27 & $V_{2} g d$ & 2002 & 7.9 & 530 & 60.2 & 16.8 & 110.0 & 8.1 & 210.0 & 190.0 & $<0.2$ & 1.20 & 3.00 & & \\
\hline 28 & $\mathrm{~V}_{2} \mathrm{vr}$ & 2002 & 7.9 & 480 & 48.5 & 16.3 & 110.0 & 7.5 & 200.0 & 160.0 & $<0.2$ & 0.37 & 2.10 & & \\
\hline 29 & $V_{2} g d$ & 2002 & 7.9 & 540 & 67.8 & 17.7 & 120.0 & 8.2 & 220.0 & 250.0 & $<0.2$ & 0.39 & 3.50 & & \\
\hline 30 & $\mathrm{~V}_{2} \mathrm{vr}$ & 2002 & 8.2 & 420 & 22.5 & 7.3 & 140.0 & 6.9 & 180.0 & 190.0 & $<0.2$ & 0.16 & 0.77 & & \\
\hline 31 & $V_{2} \mathrm{gd}$ & 2002 & 7.9 & 450 & 54.1 & 18.2 & 110.0 & 7.9 & 210.0 & 180.0 & $<0.2$ & 0.65 & 2.40 & & \\
\hline 32 & $\mathrm{~V}_{2} \mathrm{vr}$ & 2002 & 8.2 & 410 & 40.1 & 14.3 & 110.0 & 9.5 & 180.0 & 190.0 & $<0.2$ & 1.20 & 2.40 & & \\
\hline 33 & $\mathrm{Cm}-\mathrm{V}$ & 2002 & 8.1 & 460 & 32.1 & 12.4 & 130.0 & 8.3 & 190.0 & 190.0 & 0.2 & 0.09 & 2.50 & & \\
\hline 34 & $V_{2} \mathrm{gd}$ & 2001 & 7.9 & 576 & 42.3 & 15.8 & 130.0 & 7.5 & 231.0 & 183.6 & $<2$ & 0.94 & 0.81 & $<0.001$ & 0.86 \\
\hline 35 & $\mathrm{~V}_{2} \mathrm{vr}$ & 2001 & 7.9 & 640 & 44.3 & 16.9 & 130.0 & 7.5 & 233.0 & 151.3 & 2.0 & 0.92 & 0.74 & $<0.001$ & 0.86 \\
\hline 36 & $\mathrm{~V}_{2} \mathrm{gd}$ & 2001 & 8.1 & 740 & 53.1 & 17.1 & 130.0 & 8.0 & 231.0 & 196.4 & $<2$ & 0.88 & 6.37 & $<0.001$ & 0.92 \\
\hline 37 & $\mathrm{~V}_{2} \mathrm{vr}$ & 2001 & 7.9 & 696 & 56.1 & 9.1 & 200.0 & 7.0 & 316.0 & 150.1 & $<2$ & 0.62 & 0.83 & $<0.001$ & 0.76 \\
\hline 38 & $V_{2} g d$ & 2001 & 7.7 & 722 & 29.4 & 13.2 & 240.0 & 7.0 & 384.0 & 169.0 & $<2$ & 0.46 & 0.22 & $<0.001$ & 0.69 \\
\hline 39 & $\mathrm{~V}_{2} \mathrm{vr}$ & 2001 & 8.2 & 543 & 12.8 & 7.8 & 170.0 & 4.0 & 197.0 & 190.3 & $<2$ & 0.79 & 0.26 & $<0.001$ & 0.58 \\
\hline 40 & $V_{2} g d$ & 2001 & 7.9 & 1531 & 57.3 & 28.4 & 375.0 & 9.5 & 700.0 & 161.0 & 2.0 & 0.77 & 0.01 & $<0.001$ & 0.66 \\
\hline 41 & $V_{2} g d$ & 2001 & 7.8 & 1174 & 16.4 & 9.5 & 405.0 & 7.0 & 640.0 & 162.3 & $<2$ & 0.35 & 0.53 & $<0.001$ & 0.67 \\
\hline 42 & $\mathrm{~V}_{2} \mathrm{vr}$ & 2001 & 7.9 & 536 & 12.0 & 3.6 & 195.0 & 5.5 & 201.0 & 251.3 & $<2$ & 0.38 & 0.32 & $<0.001$ & 0.65 \\
\hline 43 & $\mathrm{~V}_{2} \mathrm{vr}$ & 2001 & 7.9 & 517 & 6.6 & 3.2 & 195.0 & 4.0 & 202.0 & 205.0 & $<2$ & 0.38 & 0.07 & $<0.001$ & 0.47 \\
\hline 44 & $V_{2} g d$ & 2001 & 7.9 & 531 & 7.6 & 3.6 & 200.0 & 4.0 & 208.0 & 207.4 & $<2$ & 0.48 & 0.08 & $<0.002$ & 0.52 \\
\hline $\mathrm{MCL}^{*}$ & & & -9.5 & & & & 200 & & 250 & & 250 & 0.2 & & 0.01 & 1.5 \\
\hline
\end{tabular}

* - MCL - Maximum Concentration Limit of the Estonian drinking water standard (Joogivee 2001). 
Fluorine occurs in the groundwater as $\mathrm{F}^{-}$ion and usually is contained in various organic and inorganic complexes. According to Lahermo et al. (1991) groundwaters with high $\mathrm{F}^{-}$ contents are generally $\mathrm{Na}-\mathrm{HCO}_{3}$-type waters, particularly poor in $\mathrm{Ca}^{2+}$. Handa (1975), Boyle (1992) and Saxena \& Ahmed (2001) showed that in waters with high $\mathrm{F}^{-}$concentrations, the amount of $\mathrm{F}^{-}$is proportional to the $\mathrm{HCO}_{3}$ - concentration and the $\mathrm{pH}$ value. Groundwater in the study area is mainly $\mathrm{Na}-\mathrm{Ca}-\mathrm{Cl}-\mathrm{HCO}_{3}$-type and owing to the high $\mathrm{Ca}^{2+}$ contents (Table 1), quite low amounts of $\mathrm{F}^{-}$may be mobilised. The concentrations of fluoride are, as a rule, below MCL ( $1.5 \mathrm{mg} / \mathrm{l})$, varying between $0.2-1.2 \mathrm{mg} / \mathrm{l}$ (Table 1).

The potential source of fluoride is dissolution of minerals (fluorite, clay minerals, amphiboles, pyroxenes) and ion exchange processes. In Scandinavia, groundwater with high fluoride concentrations is found in areas of young granites and pegmatites, especially postorogenic rapakivi-type granites (Aastrup et al., 1995; Banks et al., 1995; Lahermo \& Backman, 2000). Hydrochemical study performed in Norway (Sæther et al., 1995) showed that highest analysed $\mathrm{F}^{-}$values in hardrock wells are associated with gneissic host rocks and hydrothermally altered rocks. They also suggested, that the $\mathrm{F}^{-}$content of the groundwater would primarily be controlled by the presence/absence and amount of clay minerals in faults and fractures of the host rocks.

The movement and accumulation of highly reactive $\mathrm{F}^{-}$-ions depends on the complex interaction between the liquid and solid phases, like adsorption, ion exchange, precipitation and complexion (Flühler et al., 1982). Furthermore, the $\mathrm{F}^{-}$concentration in groundwater depends on the $\mathrm{pH}$, the intensity of the weathering processes, and the amount of clay and humus in the aquifer material (Omueti \& Jones, 1980; Adriano, 1986; Kabata-Pendias \& Pendias, 1992; Saxena $\&$ Ahmed, 2001). The $\mathrm{OH}^{-}$-group in micas, clay minerals and $\mathrm{Al}$-hydroxides can be replaced by $\mathrm{F}^{-}$-ions, with simultaneous release of $\mathrm{Al}$ and Fe in clay minerals (Flühler et al., 1982, Polomski et al., 1982). More than $90 \%$ of the natu-

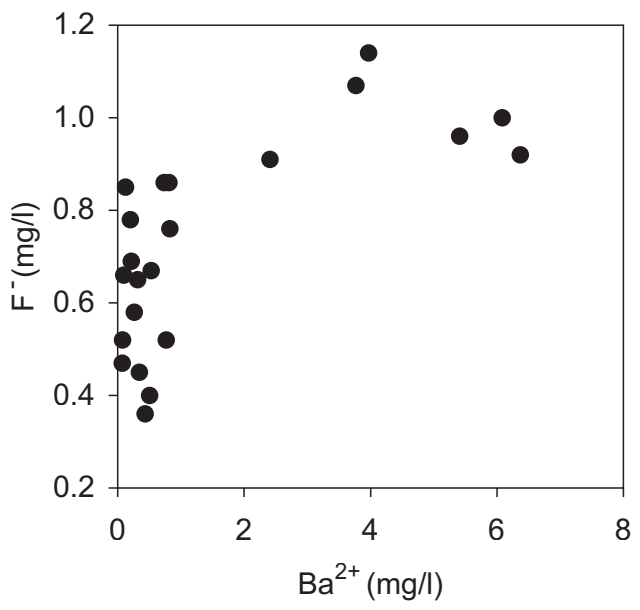

Fig. 4. Bivariate plot of $\mathrm{F}^{-}$versus $\mathrm{Ba}^{2+}$ for Cambrian-Vendian groundwaters.

ral $\mathrm{F}^{-}$in soil is thought to be tightly bound to clay particles. Thus, other physico-chemical factors of water-rock interaction may have a greater effect on the fluoride content in the groundwater than has the actual amount of fluorine in bedrock.

The crystalline basement in northern Estonia is in its upper $10-150 \mathrm{~m}$ thick portion fractured and weathered. Weathering profiles are composed predominantly of kaolinite, illite, chlorite and montmorillonite, depending on original bedrock composition and intensity of weathering (Puura et al., 1983). Such clayey formation provides adsorption and ion exchange sites for $\mathrm{F}^{-}$-ions, modifying groundwater chemistry in the hydraulically connected Cambrian-Vendian aquifer system and water bearing fractured bedrock.

Fluoride concentrations are relatively independent of the other water-soluble components. However, $\mathrm{F}^{-}$exhibits good relationship with $\mathrm{Ba}^{2+}$ contents (Fig. 4). Highest $\mathrm{F}^{-}$values coincide with anomalously high $\mathrm{Ba}^{2+}$ concentrations and are analysed from wells opening the deep-seating Gdov aquifer. Therefore, it is supposed that the geological reason for elevated $\mathrm{F}^{-}$ as well as $\mathrm{Ba}^{2+}$ in the Cambrian-Vendian aquifer system is associated with underlying weathered basement rocks. 


\subsection{Arsenic}

Arsenic is biologically very toxic element, causing serious environmental problems throughout the World (Korte \& Fernando, 1991; Hamasaki et al., 1995; Nickson et al., 1998). The consumption of groundwater with high As content causes poisoning-arsenotosis, leading to chronic and even lethal health effects (Borzonyi et al., 1992; Hopenhayn-Rich et al., 1996; Kurttio et al., 1999).

The occurrence of As in the groundwater has usually assumed to be connected with oxidation of sulphides (pyrite, arsenopyrite) during, for example, lowering of the groundwater table (Das et al., 1995). Drilled wells with high As concentration $(>0.1 \mathrm{mg} / \mathrm{l})$ in Finland are concentrated in bedrock areas where As minerals (FeAsS) occur on fracture surfaces, implying that the effectiveness of the water - arsenopyrite interaction is a major factor governing the As concentrations in bedrock groundwater (Idman, 1996). Arsenopyrite occurs most frequently in sulphide mineralizations associated with gabbros and amphibolites and bedrock wells with high As concentrations are mostly found in hydrothermally altered domains in the Precambrian bedrock. In the water bearing rocks, arsenic is also bound to oxyhydroxides, clay minerals and organic matter (Edmunds \& Smedley, 1996). Under reducing conditions, the mobilisation of As may take place during reductive dissolution of Fe-oxyhydroxides (Nickson et al., 2000).

In the areas of local basement uplifts of northern Estonia (Uljaste, Haljala and Assamalla), the basement comprises sulphidic black schists, quartzites, amphibole and pyroxene gneisses, marbles and pyroxene scarns (Puura et al., 1997). In connection of these uplifts occurs extensive hydrothermal pyrrhotite-pyrite ore mineralisation with accompanying polymetallic minerals such as sphalerite, galena, chalcopyrite, molybdenite (Koppelmaa \& Kivisilla, 1997). Thus, it is supposed that the overlying sediments and associated groundwater, reflecting the underlying bedrock composition, have the potential for natural As contamination. The re- sults of the current study, however, do not support that supposition. Analysed As values are below the analytical detection limit (Table 1) and outlining of any As-anomalies in Cambrian-Vendian groundwater is not possible. It must also be mentioned that only 21 wells are analysed for As and the risk of encountering high As concentrations in groundwater still exists and needs more detailed research in close future.

\subsection{Barium}

Barium is a naturally occurring component of minerals that are found in small, but widely distributed amounts in the earth's crust, especially in igneous rocks, sandstone, shale and coal (Kunesh, 1978). Barium enters the groundwater naturally through the weathering of rocks and minerals. However, the concentration of barium in natural waters is very low, because its dissolution is limited by baryte (BaSO4) and witherite (BaCO3) solubility products (Ball \& Nordstrom, 1991).

Barium is the only toxicant studied the content of which in water is much higher than permitted by US EPA $(2.0 \mathrm{mg} / \mathrm{l})$ in water abstracted for drinking purposes. The content of $\mathrm{Ba}^{2+}$ in the analysed water samples varies from 0.07 to $6.37 \mathrm{mg} / \mathrm{l}$ (Table 1). Territorially, the distinct distribution pattern of $\mathrm{Ba}^{2+}$ can be observed (Fig. 5). Marginal parts of the studied area are characterised by low barium content while the high $\mathrm{Ba}^{2+}$ concentrations $(0.41-6.37 \mathrm{mg} / \mathrm{l}$, median $2.41 \mathrm{mg} / \mathrm{l})$ concentrate within Kunda-Rakvere-Kohtla-Järve region, which can be outlined as Ba-anomaly in the Cambrian-Vendian aquifer system.

Generally, the deep-seated Gdov aquifer is enriched in barium compared to the overlying Voronka aquifer (Fig. 6). All high $\mathrm{Ba}^{2+}$ values $(>2 \mathrm{mg} / \mathrm{l})$ in the Gdov aquifer are associated with the anomaly. Besides, some groundwater production wells opening the Cambrian-Vendian aquifer system in its full thickness (both the Voronka and Gdov aquifer) exhibit elevated barium concentrations (Fig. 6). Among those the highest $\mathrm{Ba}^{2+}$ value $(3.77 \mathrm{mg} / \mathrm{l})$ is analysed from 


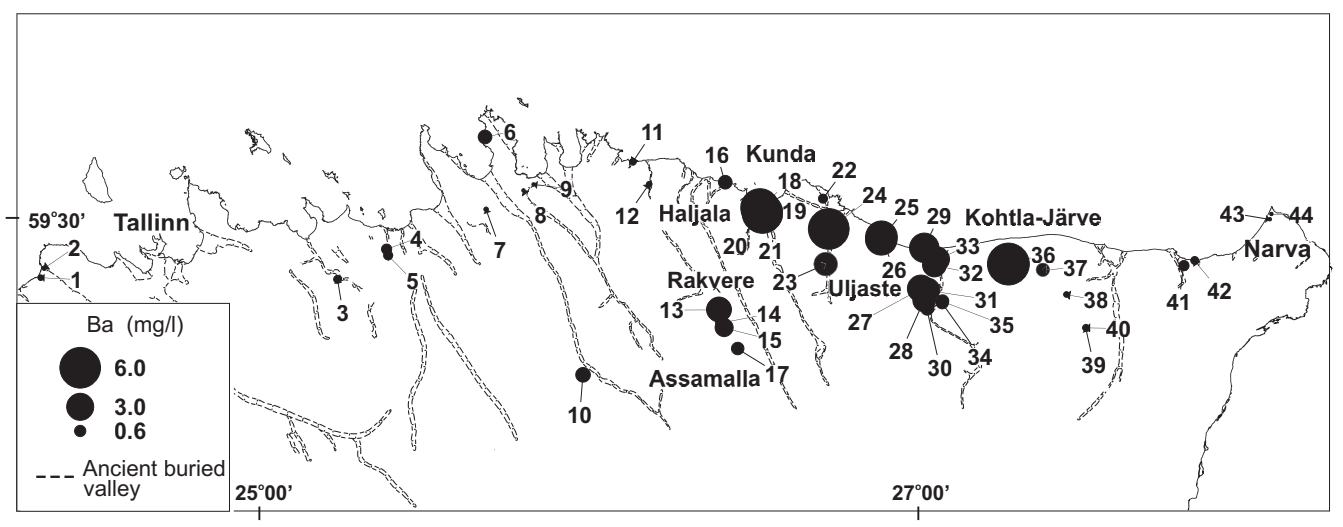

Fig. 5. The areal distribution of $\mathrm{Ba}^{2+}$ concentration in the Cambrian-Vendian aquifer system. Numbering of sampling sites in accordance with Table I.

well No. 25, which reaches 3 metres into the crystalline basement. Barium content in Voronka groundwater is usually below $1 \mathrm{mg} / \mathrm{l}$ while higher concentrations are measured in wells locating near the ancient buried valleys (wells No. $18,23,28$ and 32). These valleys act as the vertical drainage pathways between aquifers. When the hydrodynamic pressure is lowered in the Voronka aquifer as a result of groundwater consumption, the inflow from deeper Gdov aquifer into the Voronka aquifer can occur.

Barium occurs in a number of compounds, most commonly as baryte $\left(\mathrm{BaSO}_{4}\right)$ and, to a lesser extent, as witherite $\left(\mathrm{BaCO}_{3}\right)$. A likely con-

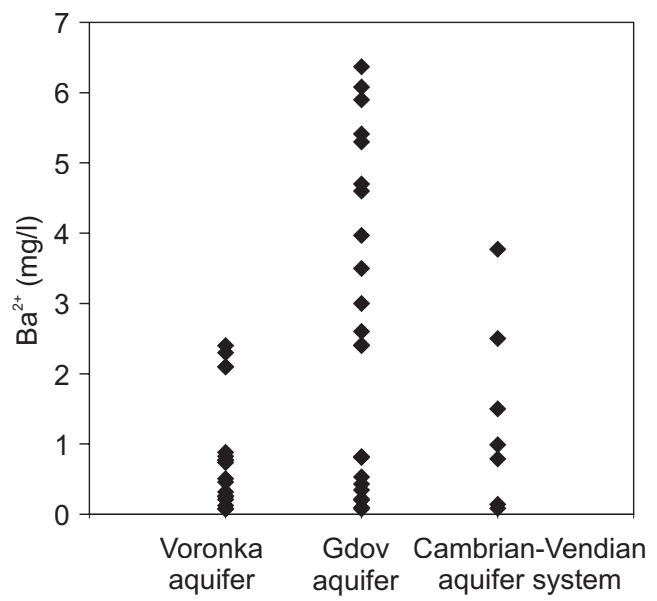

Fig. 6. Concentration of $\mathrm{Ba}^{2+}$ in different hydrogeological units. trol over the concentration of barium in natural waters is the solubility of baryte (Hem, 1985). Study by Monnin et al. (2001) shows an overall symmetrical behaviour between barium and sulphate, suggesting that the barium content in sediment pore water is controlled by equilibrium with baryte. The solubility product of this compound is near $10^{-10}$ and at sulphate concentrations $-10 \mathrm{mg} / \mathrm{l}$ or $\sim 100 \mathrm{mg} / \mathrm{l}$ the corresponding barium concentration can be $0.14 \mathrm{mg} / \mathrm{l}$ or $0.014 \mathrm{mg} / \mathrm{l}$, respectively (Hem, 1985). The concentrations of anionic complexes (sulphate and carbonate) are low in the Cambrian-Vendian aquifer system, giving thermodynamic possibility for high dissolved $\mathrm{Ba}^{2+}$ in the water.

The results of the geochemical mapping in Finland (Koljonen, 1992) showed that the highest barium contents (>650 ppm) in bedrock associate with granulites, granitoids, gneisses, mica schists and granites. Barium concentrations were found to be above the average also in the tectonic Lake Ladoga-Bothnia Bay zone and in areas where the major sulphide deposits are found. According to Klein et al. (1983) the content of barium in gneisses of Estonian crystalline basement is $700 \mathrm{ppm}$. The highest average $\mathrm{Ba}^{2+}$ content $(1000 \mathrm{ppm})$ of northeastern Estonian bedrock has been detected in silicate marbles (Koppelmaa \& Kivisilla, 1997), which are associated with hydrothermal pyrrhotite-pyrite ore mineralisations at Uljaste, Assa- 
malla and Haljala magnetic anomalies. On the other hand, barium is strongly adsorbed by clay minerals (Lagas et al., 1984; Kabata-Pendias \& Pendias, 1992) and by metal oxides and hydroxides (Hem, 1985). Weathering core of basement rocks is composed predominantly of kaolinite, illite, chlorite and montmorillonite providing adsorption sites also for $\mathrm{Ba}^{2+}$ ions.

The screens of groundwater abstraction wells opening Gdov aquifer reach close to the weathered basement, which is hydraulically connected with overlying Cambrian-Vendian aquifer system. Thus, as the influence area of pumping increases, the increasing contribution of the upconing of deep-seated water from the bedrock and its weathering core modifies the groundwater chemistry in the Cambrian-Vendian aquifer system.

Due to the scarcity of minor and trace element analyses from the weathering core of the crystalline basement and water bearing Vendian rocks, it is difficult to make any ultimate conclusions on the sources of barium as well as fluoride in groundwater. Thus, the exact identification of geological source of given elements needs detail sampling and chemical analysing of rocks and the weathering core.

\section{Conclusions}

The results of hydrogeochemical mapping performed in northern Estonia show that fluorine concentrations in the Cambrian-Vendian aquifer system are below the limit value set for drinking water $(1.5 \mathrm{mg} / \mathrm{l})$. The arsenic con-

\section{References}

Aastrup, M., Thunholm, B., Johnson, J., Bertills, U. \& Berntell, A., 1995. Groundwater chemistry in Sweden. Swedish Environmental Protection Agency and Geological Survey of Sweden. Report 4416, 52 p.

Adriano, D.C., 1986. Trace elements in the terrestrial environment. Springer-Verlag, New York, 533 p.

Apambire, W.B., Boyle, D.R. \& Michel, F.A., 1997. Geochemistry, genesis, and health implications of fluoriferous groundwaters in the upper regions of Ghana. Environmental Geology 33, 13-24.

Ball, J.W. \& Nordstrom, D. K., 1991. WATEQ4F User's Manual With Revised Thermodynamic Da- tent is mostly under analytical quantification limit $(0.001 \mathrm{mg} / \mathrm{l})$. Anomalously high barium concentrations (up to $6.4 \mathrm{mg} / \mathrm{l}$ ) in abstracted groundwater are associated with wells of Kunda, Rakvere and Kohtla-Järve cities. Clear vertical Ba-distribution can be followed-the deepseated Gdov aquifer is enriched with $\mathrm{Ba}^{2+}$ compared to the overlying Voronka aquifer.

The crystalline basement and its weathering core, which are hydraulically connected with the overlying Vendian and Cambrian terrigenous rocks, are the probable sources of barium and fluorides in groundwater. The intrusion of deep-seated and saline groundwater by intensive exploitation of wells is possible.

The wells discharging water with high $\mathrm{Ba}^{2+}$ concentration should be monitored and, if needed, water treatment should be provided or the wells closed. Because of the potential toxicity of barium, fluorides and arsenic it would be necessary to undertake a systematic and detailed study of the relationship between water chemistry and the host lithology. The results of the current pilot study provide new background information for future research.

\section{Acknowledgements}

This study was financially supported by Estonian Science Foundation grant No 4906 and the Estonian National Environmental Monitoring Program. We appreciate the comments by Dr. Pertti Lahermo and Dr. Rein Vaikmäe that enabled to improve the manuscript.

Editorial handling: Timo Tarvainen ta Base and Test Cases for Calculating Speciation of Major, Trace and Redox Elements in Natural Waters. USGS Open-File Report 90-129, U.S. Geological Survey, 185 p.

Banks, D., Reimann, C., Røyset, O., Skarphagen, H. \& Sæther, O.M., 1995. Natural concentrations of major and trace elements in some Norwegian bedrock groundwaters. Applied Geochemistry 10, 1-16.

Borzonyi, M., Bereczky, A., Rudnai, P., Csanady, M. \& Horvath, A., 1992. Epidemiological studies on human subjects exposed to arsenic in drinking water in Southeast Hungary. Archives Toxicological 66, 77-78. 
Boyle, D.R., 1992. Effects of base exchange softening on fluoride uptake in groundwaters of the Moncton Subbasin, New Brunkswick, Canada. In: Kharaka, Y.K. \& Maest, A.S. (eds.) Water-rock interaction. Proc. $7^{\text {th }}$ Int. Symp. Water-rock interaction. A.A. Balkema, Rotterdam, 771-774.

Council Directive 98/83/EEC, 1998. On the quality of water intended for human consumption (revision of Council Directive 80/778/EEC).

Das, D., Basu, G., Chowdhury, T.R. \& Chakraborty, D., 1995. Bore-hole soil-sediment analysis of some As affected areas. Proceedings of International Conference on Arsenic in Groundwater: cause, effect and remedy. Calcutta, 44-45.

Edmunds, W.E. \& Smedley, P.L., 1996. Groundwater geochemistry and health: an overwiev. In: Appelton, J.D., Fuge, R. \& McCall, G.J.H. (eds.) Environmental Geochemistry and Health. The London Geological Society, London, 91-105.

EPA, 1995. Contaminant Specific Fact Sheets. Inorganic Chemicals - Consumer Version. National Primary Drinking Water Regulations. EPA 811-F-95-002C, October 1995.

Flühler, H., Polomski, J. \& Blaser, P., 1982. Retention and movement of fluoride in soil. Journal of Environmental Quality 11, 461-468.

Grimaldo, M., Borja-Aburto, V.H., Ramirez, A.L., Ponce, M., Rosas, M. \& Diaz-Barriga, F., 1995. Endemic fluorosis in San Luis Potosi, Mexico. Identification of risk factors associated with human exposure to fluoride. Environmental Research 68, 25-30.

Hamasaki, T., Nagase, H., Yoshioka,Y. \& Sato, T., 1995. Formation, distribution and ecotoxicity of methylmetals of tin, mercury and arsenic in the environment. Critical Rewievs of Environmental Science Technology 25, 45-91.

Handa, B.K., 1975. Geochemistry and genesis of fluoride-containing ground waters in India. Ground Water 13, 275-281.

Hem, J., 1985. Study and interpretation of the chemical characteristics of natural waters. U.S. Geol. Survey Water-Supply Paper 2254, 263 p.

Hopenhayn-Rich, C., Biggs, M.L., Fuchs, A., Bergoglio, R., Telo, E.E., Nicolli, H. \& Smith, A.H., 1996. Bladder cancer mortality associated with arsenic in drinking water in Argentina. Epidemiology 7, 117-124.

Idman, H., 1996. Luonnollisen arseenipitoisuuden vaihtelu pohjavesissä ja siihen vaikuttavat tekijät. Abstract: Naturally occurring arsenic in groundwaters and factors affecting its concentration. Suomen Ympäristö 71, 17-22.

Joogivee kvaliteedi-ja kontrollinôuded ning analüüsimeetodid 2001. SOMm RTL 1001369.

Joogivesi. Üldnôuded Eesti standard EVS 663, 1995. Eesti Standardiamet.

Kabata-Pendias, A. \& Pendias, H., 1992. Trace elements in soils and plants. CRC Press, Inc. Boca Raton, $365 \mathrm{p}$.

Karise, V., 1997. Composition and properties of groundwater under natural conditions. In: Raukas, A. \& Teedumäe, A. (eds.) Geology and mineral resources of Estonia. Estonian Academy Publishers, Tallinn, 152156.

Klein, V., Kivisilla, J. \& Koppelmaa, H., 1983. Aruanne mineraal-petroloogilistest uurimustest Póhja-Eesti metamorfsetes kompleksides, alamproterosoikum. Aruanne 3982, Eesti Geoloogiakeskus, Keila, 204 p.
Koistinen, T., Klein, V., Koppelmaa, H., Lahtinen, R., Nironen, M., Puura, V., Saltykova, T., Tikhomirov, S. \& Yanovskiy, A., 1996. Paleoproterozoic Svecofennian orogenic belt in the surroundings of the Gulf of Finland. In: Koistinen, T. (ed.) Explanation to the Map of Precambrian basement of the Gulf of Finland and surrounding area 1:1 million. Geological Survey of Finland, Special Paper 21, 21-57.

Koljonen, T. (ed.), 1992. The Geochemical Atlas of Finland, part 2: Till. Geological Survey of Finland, Espoo, $218 \mathrm{p}$

Koppelmaa, H. \& Kivisilla, J., 1997. Geological map of the crystalline basement of North-Eastern Estonia. Scale 1:200 000. Explanation to the map. Geological Survey of Estonia, Tallinn, $37 \mathrm{p}$.

Korte, N.E. \& Fernando, Q., 1991. A rewiev of arsenic (III) in groundwater. Critical Reviews of Environmental Control 21, 1-39.

Kunesh, C.J., 1978. Barium. In: Grayson, M. \& Eckroth, D. (eds.) Kirk-Othmer encyclopedia of chemical technology. Vol. 3, 3rd ed., John Wiley and Sons, New York, 457-463.

Kurttio, P., Pukkala, E., Kahelin, A., Auvinen, A. \& Pekkanen, J., 1999. Arsenic concentrations in well water and risk of bladder and kidney cancer in Finland. Environmental Health Perspectives 107, 705-710.

Lagas, P., Loch, J.P.G. \& Born, C.M., 1984. The behaviour of barium in a landfill and the underlying soil. Water, Air and Soil Pollution 22, 121-129.

Lahermo, P. \& Backman, B., 2000. The occurrence and geochemistry of fluorides with special reference to natural waters in Finland. Report of Investigation 149. Geological Survey of Finland, Espoo, 40 p.

Lahermo, P., Sandström, H. \& Malisa, E., 1991. The occurrence and geochemistry of fluorides in natural waters in Finland and East Africa with reference to their geomedical implications. Journal of Geochemical Exploration 41, 65-79.

Marandi, A., Karro, E. \& Puura, E., 2002. Baariumi anomaalia Kambriumi-Vendi veekompleksi pōhjavees. Rmt.: Roose, A. (toim.) Eesti Keskkonnaseire 2001. Tartu Ülikooli Kirjastus, Tartu, 52-53.

Mokrik, R., 1997. The palaeohydrogeology of the Baltic Basin. Tartu University Press, Tartu, 138 p.

Monnin, C., Wheat, G., Dupre, B., Elderfield, H. \& Mottl, M., 2001. Barium geochemistry in sediment pore waters and formation waters of the oceanic crust on the eastern flank of the Juan de Fuca Ridge (ODP Leg 168). Geochemistry, Geophysics, Geosystems, an electronic journal of Earth Sciences 2, 8 January 2001.

Nickson, R.T., McArthur, J., Burgess, W., Ahmed, K.M., Ravenscroft, P. \& Rahman, M., 1998. Arsenic poisoning of Bangladesh groundwater. Nature 395, 338.

Nickson, R.T., McArthur, J., Ravenscroft, P., Burgess, W. \& Ahmed, K.M., 2000. Mechanism of arsenic release to groundwater, Bangladesh and West Bengal. Applied Geochemistry 15, 403-413.

Omueti, J.A.I. \& Jones, R.L., 1980. Fluorine distribution with depth in relation to profile development in Illinois. Soil Science Society of America Journal 44, 247-249.

Otsa, E. \& Tamm, I., 1997. Kirde-Eesti tööstuspiirkonna reostunud põhjavee seire. Rmt: Roots, O. \& Talkop, R. (toim.) Eesti Keskkonnaseire 1996. Tallinn, 157159. 
Perens, R. \& Vallner, L., 1997. Water-bearing formation. In: Raukas, A. \& Teedumäe, A. (eds.) Geology and mineral resources of Estonia. Estonian Academy Publishers, Tallinn, 137-145.

Perens, R., Savva, V., Lelgus, M. \& Parm, T., 2001. The hydrogeochemical atlas of Estonia (CD version). Geological Survey of Estonia, Tallinn.

Polomski, J., Flühler, H. \& Blaser, P., 1982. Fluoride induced mobilisation and leaching of organic matter, iron and aluminium. Journal of Environmental Quality $11,452-456$.

Puura, V., Klein, V., Koppelmaa, H. \& Niin, M., 1997. Precambrian basement. In: Raukas, A. \& Teedumäe, A. (eds.) Geology and mineral resources of Estonia. Estonian Academy Publishers, Tallinn, 27-34.

Puura, V., Vaher, R., Klein, V., Koppelmaa, H., Niin, M., Vanamb, V. \& Kirs, J., 1983. The crystalline basement of Estonian territory. Nauka, Moscow, 208 p.

Russak, S., Indermitte, E. \& Saava, A., 2002. Hambafluoroosi ja -kaariese haigestumus Tartu linna lastel seoses joogivee fluorisisaldusega. Eesti Antropomeetria Registri aastaraamat 2002, 178-193.

Saava, A., 1998. Health hazards due to drinking water. Proceedings of the Latvian Academy of Sciences, Section B, 52, 162-167.

Saether, O.M., Reimann, C., Hilmo, B.O. \& Taushani, E., 1995. Chemical composition of hard- and softrock groundwaters from central Norway with special consideration of fluoride and Norwegian drinking water limits. Environmental Geology 26, 147-156.
Savitskaja, L., 1999. Pōhjavee seisund 1997-1998. aastal. Eesti Geoloogiakeskus, Tallinn, 112 p.

Savitskaja, L. \& Viigand, A., 1994. Aruanne kabrium-vendi veekompleksi póhjavee mikrokomponentide ja isotoopkoostise uurimisest joogivee kvaliteedi hindamiseks Póhja-Eestis. Eesti Geoloogikeskus, Tallinn, $95 \mathrm{p}$.

Saxena, V.K. \& Ahmed, S., 2001. Dissolution of fluoride in groundwater: a water-rock interaction study. Environmental Geology 40, 1084-1087.

Tamm, I., 1998. Kirde-Eesti ja Kunda Kambrium-Vendi póhjavee raskemetallide seire aastatel 1996-1998. AS Maves, Tallinn.

Tavast, E., 1997. Bedrock topography. In: Raukas, A. \& Teedumäe, A. (eds.) Geology and mineral resources of Estonia. Estonian Academy Publishers, Tallinn, 252-255.

WHO, 1996. Guidelines for drinking-water quality. $2^{\text {nd }}$ ed. Vol. 2. Health criteria and other supporting information. World Health Organisation, Geneva.

Yang, C.H., Cheng, M.F., Tsai, S.S. \& Hung, C.F., 2000. Fluoride in drinking water and cancer mortality in Taiwan. Environmental Research 82, 189-193.

Yong, L. \& Hua, Z.W. 1991. Environmental characteristics of regional groundwater in relation to fluoride poisoning in North China. Environmental Geology and Water Science 18, 3-10. 